\title{
Peripheral Role of Cathepsin S in Th1 Cell-Dependent Transition of Nerve Injury-Induced Acute Pain to a Chronic Pain State
}

\author{
Xinwen Zhang, ${ }^{1 *}$ Zhou Wu, ${ }^{1 *}$ Yoshinori Hayashi, ${ }^{1 \star}$ Ryo Okada, ${ }^{1}$ and Hiroshi Nakanishi ${ }^{1,2}$ \\ ${ }^{1}$ Department of Aging Science and Pharmacology, Faculty of Dental Science, Kyushu University, Fukuoka 812-8582, Japan, and ${ }^{2} J a p a n$ Science and \\ Technology Agency, CREST, Tokyo, 102-0075, Japan
}

\begin{abstract}
There is increasing evidence that $\mathrm{CD} 4{ }^{+} \mathrm{T}$-cell-dependent responses are associated with the maintenance of neuropathic pain. However, little is known about the precise mechanism(s) underlying the activation of $\mathrm{CD} 4{ }^{+} \mathrm{T}$-cells. We herein show that inhibition of cathepsin $\mathrm{S}$ (CatS) activity, either through genetic deletion or via a pharmacological inhibitor, Z-Phe-Leu-COCHO (Z-FL), significantly attenuated the maintenance of tactile allodynia, splenic hypertrophy, increased number of splenic $\mathrm{CD} 4{ }^{+}$T-cells and the final cleavage step of the MHC class II-associated invariant chain following peripheral nerve injury. It was also noted that splenectomy significantly attenuated the peripheral nerve injury-induced tactile allodynia, whereas the adoptive transfer of splenic $\mathrm{CD} 4{ }^{+} \mathrm{T}$-cells from neuropathic wild-type mice significantly increased the pain level of splenectomized wild-type or CatS ${ }^{-1-}$ mice. Furthermore, CatS deficiency or Z-FL treatment also significantly inhibited the infiltration of $\mathrm{CD} 4{ }^{+}$T-cells that expressed interferon- $\gamma($ IFN- $\gamma$ ) in the dorsal spinal cord. Signal transducer and activator of transcription 1, a molecule downstream of IFN- $\gamma$ receptor activation, was activated exclusively in microglia $7 \mathrm{~d}$ after peripheral nerve injury. Moreover, CatS deficiency, Z-FL treatment, or splenectomy significantly attenuated the proliferation of microglia $14 \mathrm{~d}$ after peripheral nerve injury. These results show a peripheral pivotal role of Cat $S$ in the development of neuropathic pain through the antigen-specific activation of $\mathrm{CD} 4^{+}$T-cells. After activation, $\mathrm{CD} 4{ }^{+}$T-cells infiltrate into the dorsal spinal cord and secrete IFN- $\gamma$ to reactivate microglia, which contribute to the transition of acute pain to a chronic pain state.
\end{abstract}

Key words: cathepsin S; dendritic cells; interferon-ganmma; microglia; neuropathic pain; Th1 cells

\section{Introduction}

Neuropathic pain is a chronic pain condition associated with lesions or dysfunction of the nervous system. This pain may become refractory to conservative medical management, leading patients to suffer from a reduction in their quality of life. It is now widely believed that neuropathic pain is induced by spinal microglia-mediated responses (Watkins et al., 2001; Tsuda et al., 2003; Scholz and Woolf, 2007). Although the mechanism(s) underlying the maintenance of neuropathic pain are rather poorly understood, there is accumulating evidence that $\mathrm{CD} 4^{+} \mathrm{T}$-celldependent responses are associated with the maintenance of neuropathic pain. First, T-cells cross the blood-spinal cord barrier to infiltrate in the dorsal spinal cord after peripheral nerve injury (Cao and DeLeo, 2008; Costigan et al., 2009). Second, animals

\footnotetext{
Received Aug. 28, 2013; revised Jan. 15, 2014; accepted Jan. 15, 2014.

Author contributions: H.N. designed research; X.Z., Z.W., Y.H., and R.O. performed research;X.Z., Z.W., Y.H., and H.N. analyzed data; X.Z., Z.W., Y.H., and H.N. wrote the paper.

This work was supported by the Japan Science and Technology Agency, CREST, and Grants-in-Aid from Ministry of Education, Culture, Sports, Science and Technology, Japan. X.Z. was supported by an Iwadare Scholarship and an Otsuka Toshimi Scholarship.

*X.Z., Z.W., and Y.H. contributed equally to this work.

The authors declare no competing financial interests.

Correspondence should be addressed to Dr Hiroshi Nakanishi, Department of Aging Science and Pharmacology, Faculty of Dental Sciences, Kyushu University, Fukuoka, 812-8582, Japan. E-mail: nakan@dent.kyushu-u.ac.jp.

DOI:10.1523/JNEUROSCI.3681-13.2014

Copyright $\odot 2014$ the authors $\quad 0270-6474 / 14 / 343013-10 \$ 15.00 / 0$
}

lacking functional T-cells demonstrate reduced neuropathic tactile allodynia (Moalem et al., 2004; Cao and DeLeo, 2008; Costigan et al., 2009). Third, the reduced neuropathic tactile allodynia in these animals can be reversed by the adoptive transfer of splenic $\mathrm{CD}^{+}{ }^{+}$T-cells prepared from neuropathic animals (Moalem et al., 2004; Cao and DeLeo, 2008). Finally, mice lacking interferon- $\gamma($ IFN- $\gamma)$ receptors showed significant attenuation of the peripheral nerve injury-induced activation of spinal microglia (Tsuda et al., 2009) and tactile allodynia (Costigan et al., 2009; Tsuda et al., 2009). Together, these studies showed that the interaction between infiltrated $\mathrm{CD} 4{ }^{+} \mathrm{T}$-cells and microglia in the dorsal spinal cord plays an essential role in the maintenance of neuropathic pain. Therefore, it is important to determine how $\mathrm{CD} 4{ }^{+}$T-cells become activated following peripheral nerve injury, because the $\mathrm{CD} 44^{+} \mathrm{T}$-cells in the spleen and lymph node must be activated to cross the blood-spinal cord barrier.

$\mathrm{CD} 4{ }^{+} \mathrm{T}$-cell-dependent responses are initiated by the recognition of MHC class II-peptide complexes on antigen-presenting cells. During this process, the invariant chain (Ii) is sequentially cleaved to leupeptin-induced peptide 10 (lip10) and finally to class II-associated Ii peptide (CLIP), which remains in the peptide-binding groove (Nakagawa et al., 1999; Riese et al., 2001). Human leukocyte antigen DM then catalyzes the removal of CLIP from the class II molecules, enabling the binding of antigenic peptides. Then, the class II-peptide complex traffics to the 
cell surface, where it presents the antigen to cognate T-cells, initiating an immune response (Villadangos et al., 1997).

Cathepsin S (CatS; EC 3.4.22.27), a lysosomal cysteine protease preferentially expressed in mononuclear-phagocytic cells (Petanceska et al., 1996), is responsible for the final proteolytic cleavage stage of Ii from lip10 to CLIP in antigen presenting cells, including dendritic cells (Driessen et al., 1999; Nakagawa et al., 1999; Shi et al., 1999; Riese et al., 2001; Nakanishi, 2003). The inhibition of CatS activity, either through pharmacological means or by genetic deletion, significantly reduces chronic diseases caused by functional $\mathrm{CD} 4^{+} \mathrm{T}$-cell-dependent responses, including collagen-induced arthritis and autoimmune myasthenia gravis.

We thus hypothesized that the peripheral enzymatic activity of CatS is necessary for the maintenance of neuropathic pain through the antigen-specific activation of $\mathrm{CD} 4{ }^{+} \mathrm{T}$-cells. To confirm this hypothesis, we examined the effects of a genetic CatS deficiency and a specific CatS inhibitor on the $\mathrm{CD} 4^{+} \mathrm{T}$-celldependent responses and pain behaviors following peripheral nerve injury. We herein provide the first evidence that the peripheral enzymatic activity of CatS critically contributes to the transition of acute pain to a chronic pain state following peripheral nerve injury.

\section{Materials and Methods}

Animal. Eight- to 10-week-old male wild-type mice and CatS-deficient $\left(\mathrm{CatS}^{-/-}\right)$mice on a DBA/2 background were used for the experiments. Genotyping was performed as described previously (Hao et al., 2007). The mice were maintained on a $12 \mathrm{~h}$ light/dark cycle (light on at 8:00 A.M.) under conditions of $22-25^{\circ} \mathrm{C}$ ambient temperature with food and water ad libitum. All mice were handled daily for $5 \mathrm{~d}$ before the start of the experiment to minimize their stress reactions to manipulation. All animals were treated in accordance with the guidelines stipulated by the animal care and use committee of Kyushu University.

Construction of the pain models. For the neuropathic pain model, mice were anesthetized with sodium pentobarbital $(50 \mathrm{mg} / \mathrm{kg}$, i.p.). The L4 spinal nerves were carefully separated from adjacent nerves, and then transected as reported previously (Hayashi et al., 2011). In some experiments, a $0.5 \mathrm{~cm}$ incision was made on the left lateral abdomen and then a splenectomy was performed. The L4 nerve was transected $24 \mathrm{~h}$ after the splenectomy. For the inflammatory pain model, 8- to 10-week-old male wild-type mice and CatS ${ }^{-1-}$ mice were injected with Complete Freund's adjuvant (CFA; heat-killed Mycobacterium butyricum were well suspended in mineral oil, $10 \mathrm{mg} / \mathrm{ml}, 20 \mu \mathrm{l}$ ) into one of the footpads or saline (mineral oil, $20 \mu \mathrm{l}$ ) into the other footpads under enflurane $/ \mathrm{O}_{2}$ as reported previously (Sun et al., 2012) The paw diameter was measured using a micrometer caliper (ThermoFisher Scientific).

Drug administration. Z-Phe-Leu-COCHO (Z-FL; Calbiochem), a specific inhibitor of CatS (Walker et al., 2000), was intraperitoneally (i.p.) administered $1 \mathrm{~h}$ before behavioral the analyses. Drug administration was started before or $5 \mathrm{~d}$ after peripheral nerve injury. Z-FL was administered at 1,10 , or $20 \mu \mathrm{g} / 10 \mathrm{~g}$ (i.p.), with $n=6$ for each group.

Behavioral analysis. All mice were habituated to the testing environment for $3 \mathrm{~d}$. All mice were tested for mechanical hypersensitivity of the hindpaw $1 \mathrm{~d}$ before and 2 weeks after surgery (Hayashi et al., 2011; Sun et al., 2012). Neuropathic tactile allodynia was analyzed $1 \mathrm{~h}$ after Z-FL treatment. On day 14 after peripheral nerve injury, splenocytes were isolated from wild-type and CatS ${ }^{-1-}$ mice, then injected into splenectomized mice $5 \mathrm{~d}$ after peripheral nerve injury. Calibrated von Frey filaments (0.02-2.0 g; North Coast Medical) were applied to the planter surface of the hindpaw. The $50 \%$ paw withdrawal thresholds were calculated using the up-down method (Chaplan et al., 1994).

Motor activities. The motor activities of wild-type and CatS ${ }^{-1-}$ mice were measured using cylinder and rotarod tests. The cylinder and rotarod tests were conducted according to the methods previously described (Hayashi et al., 2008).
Cell isolation. Splenocytes, $\mathrm{CD} 4{ }^{+}$cells and $\mathrm{CD} 11 \mathrm{~b}^{+}$cells were isolated from the mouse spleens. Wild-type mice anesthetized and perfused transcardially with PBS on day 14 postinjury. Ten mice in each group were anesthetized and perfused transcardially with PBS, and then the spleen samples were cut into small pieces. After enzymatic digestion using the Neural Tissue Dissociation Kit (Papain), the cell suspensions were further mechanically dissociated using a gentle MACS Dissociator (Milteny Biotec), and single splenocyte suspensions were obtained after the samples were applied to a $30 \mu \mathrm{m}$ cell strainer. After removed the red blood cells by Red Blood Cell Lysis Solution (Miltenyi Biotec), the CD11b ${ }^{+}$ cells were magnetically labeled with CD11b MicroBeads, and CD4 ${ }^{+}$cells were labeled with a PE-conjugated anti-CD4 (Miltenyi Biotec) antibody and anti-PE MicroBeads. The cell suspension was loaded onto a MACS column placed in the magnetic field of a MACS separator and the $\mathrm{CD} 1 \mathrm{~b}^{+}$cells or $\mathrm{CD} 4{ }^{+}$cells were eluted after removing the magnetic field according to the methods previously described methods (Wu et al., 2013). Each of the splenectomized mice and $\mathrm{CatS}^{-1-}$ mice group respectively received an intraperitoneal injection of $2 \times 10^{7}$ splenocyte, CD4 ${ }^{+}$ cells or $\mathrm{CD}_{1} \mathrm{bb}^{+}$cells from donors in $200 \mu \mathrm{l}$ of PBS $5 \mathrm{~d}$ after peripheral nerve injury.

Immunohistochemistry. Mouse tissues were examined by an immunohistochemical analysis as described previously (Hayashi et al., 2011; Sun et al., 2012). All mice were deeply anesthetized with somnopentyl (50 $\mathrm{mg} / \mathrm{kg}$, i.p.) and perfused transcardially with $0.1 \mathrm{M}$ phosphate buffer (PB), $\mathrm{pH} 7.4$, followed by $4 \%$ paraformaldehyde in $0.1 \mathrm{M} \mathrm{PB}, 14 \mathrm{~d}$ after surgery ( $n=3$ animals at each time point). The perfused spleen segments were dissected and further fixed by immersion in $4 \%$ paraformaldehyde overnight at $4^{\circ} \mathrm{C}$. Transverse spleen sections ( $14 \mu \mathrm{m}$ thick) were prepared using by a cryostat (VT1000S; Leica). The sections were hydrated and treated with $0.3 \% \mathrm{H}_{2} \mathrm{O}_{2}$ in methanol, and then were treated with $3 \%$ normal donkey serum for $2 \mathrm{~h}$ at $24^{\circ} \mathrm{C}$. The sections were incubated with the rat anti-CD4 (1:500; BD PharMingen) or rabbit anti-IFN- $\gamma$ (1: 1000; Life Technologies) antibodies in a humidified chamber overnight at $4^{\circ} \mathrm{C}$. After being washed with cold PBS, the sections were incubated with biotinylated-anti-rat secondary antibodies (1:200; Jackson ImmunoResearch) or biotinylated anti-rabbit secondary antibodies (1:200; Jackson ImmunoResearch) for $2 \mathrm{~h}$ at $24^{\circ} \mathrm{C}$, and finally with peroxidase-conjugated streptavidin (1:300; Dako) for $1 \mathrm{~h}$ at $24^{\circ} \mathrm{C}$. The peroxidase was developed using 3,30-diaminobenzidine (DAB substrate kit; Vector Laboratories), and then the samples were counterstained with Mayer's hematoxylin. The number of the positive cells in the footpads was counted under a $20 \times$ objective ( 3 sections/mouse, $n=3$ ).

Double-immunofluorescent staining. The samples of the L4-L5 spinal cords or spleens from wild-type and $\mathrm{CatS}^{-1-}$ mice were obtained 7 or $14 \mathrm{~d}$ after the peripheral nerve injured or sham-operated mice. The samples were cryoprotected at $4^{\circ} \mathrm{C}$ for $2 \mathrm{~d}$ in $30 \%$ sucrose in PBS, and then were embedded in an optimal cutting temperature compound (Sakura Finetechnical). Serial coronal frozen sections $(14 \mu \mathrm{m})$ of the samples for double-immunofluorescent staining were prepared as reported previously (Sun et al., 2012). In the samples of spinal cords, the sections were then incubated with antibodies: rat anti-CD3 (1:500; BD PharMingen) with rabbit anti-IFN- $\gamma$ (1: 1000; Life Technologies), goat anti-phosphosignal transducer and activator of transcription 1 (pSTAT1, Tyr 701, 1: 200; Santa Cruz Biotechnology) with rabbit anti-Ibal (1:10,000; Wako), rabbit anti-GFAP (1: 5000; Sigma-Aldrich), or mouse anti-NeuN (1: 5000; Millipore), rabbit anti-Ibal (1:10,000) with goat anti-CatS (M-19, 1:500; Santa Cruz Biotechnology) or goat anti-cystatin C (CysC; 1: 500; R\&D Systems), rabbit anti-GFAP (1:5000) and goat anti-CatS (1:500) or goat anti-CysC (1: 500), mouse anti-NeuN (1:5000) with goat anti-CatS (1:500) or goat anti-CysC (1: 500) antibodies for $2 \mathrm{~d}$ at $4^{\circ} \mathrm{C}$. The sections were washed with PBS and incubated with a mixture of secondary antibodies conjugated with donkey anti-rabbit AlexaFluor 488 (1:400; Jackson ImmunoResearch) and donkey anti-rat Cy3 (1:400; Jackson ImmunoResearch), donkey anti-goat AlexaFluor 488 (1:400; Jackson ImmunoResearch) and donkey anti-rabbit Cy3 (1:400; Jackson ImmunoResearch) or donkey anti-mouse Cy3 (1:500; Jackson ImmunoResearch), donkey anti-goat AlexaFluor 488 (1:400), and donkey anti-rabbit Cy3 (1:400) or donkey anti-mouse $\mathrm{Cy} 3(1: 500)$ for $3 \mathrm{~h}$ at $24^{\circ} \mathrm{C}$. In the samples of spleen, the sections were then incubated with antibodies: rat anti-CD4 (1:500) with 
A
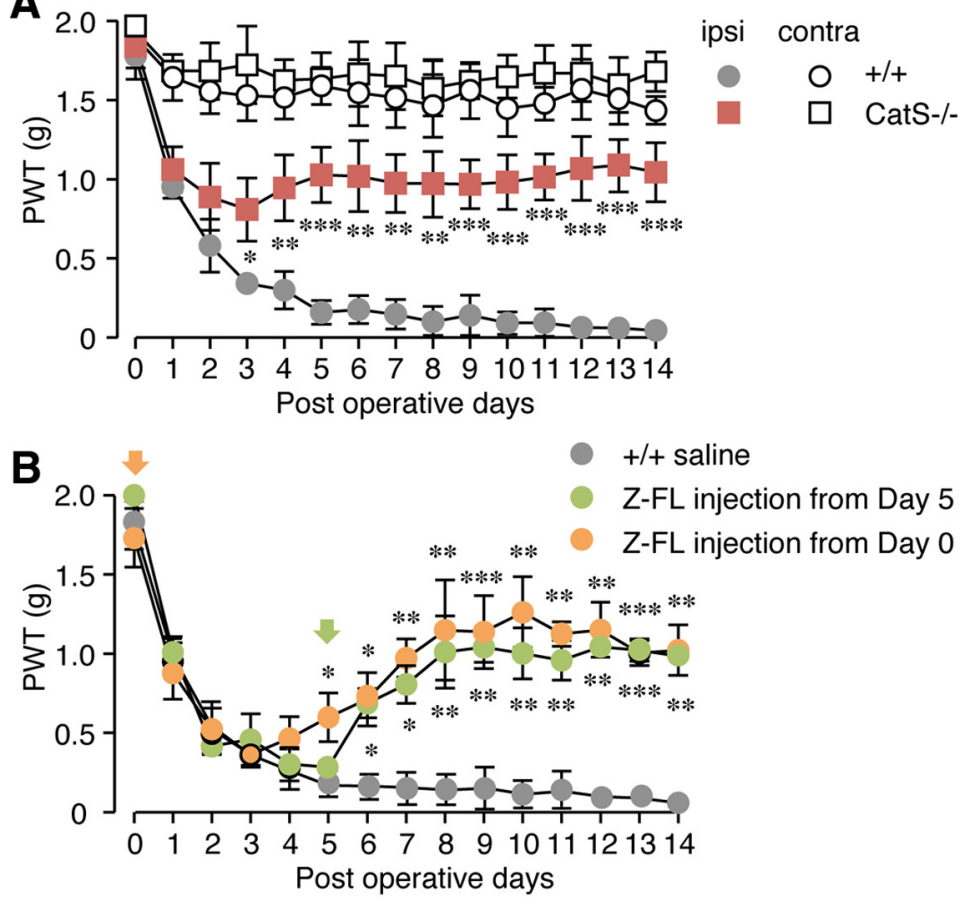

C

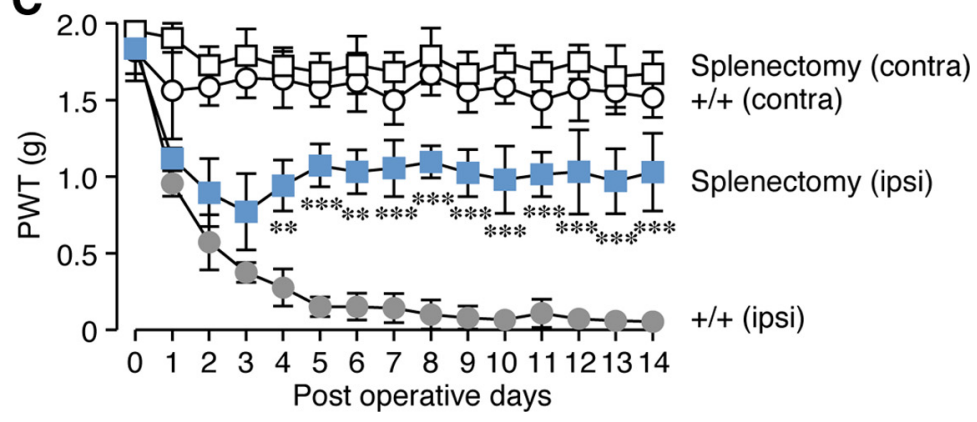

Figure 1. The inhibitory effects of the genetic deletion and pharmacological inhibition of Cat $S$ on the development of neuropathic tactile allodynia. $\boldsymbol{A}$, The time course of changes in the PWT after peripheral nerve injury (PNI) in the wild-type $(+/+)$ and $\mathrm{CatS}^{-1-}$ mice. Each symbol and vertical bar represents the mean \pm SEM of six independent experiments. Asterisks indicate a statistically significant difference from wild-type mice $\left({ }^{*} p<0.05,{ }^{* *} p<0.01\right.$, $\left.{ }^{* * *} p<0.001\right)$. $\boldsymbol{B}$, The inhibitory effects of intraperitoneal administration of Z-FL (10 $\mu \mathrm{g} / 10 \mathrm{~g})$, a specific inhibitor of CatS, on the development of neuropathic tactile allodynia. Daily peritoneal administration of Z-FL was started on day 0 (blue circles) or day 5 (red circles) after PNI. Each symbol and vertical bar represents the mean \pm SEM of five to six independent experiments. Asterisks indicate a statistically significant difference from the saline-treated wild-type mice $\left({ }^{*} p<0.05,{ }^{* *} p<0.01,{ }^{* * *} p<0.001\right)$. C, The inhibitory effects of splenectomy on the development of neuropathic tactile allodynia. Each symbol and vertical bar represents the mean \pm SEM of six independent experiments. Asterisks indicate a statistically significant difference from wild-type mice $\left.{ }^{* *} p<0.01,{ }^{* * *} p<0.001\right)$. conducted as described previously (Hayashi et al., 2011; Sun et al., 2012). In brief, each specimen was electrophoresed using $15 \%$ or $12 \%$ SDS-polyacrylamide gels. The proteins on SDS gels were transferred electrophoretically to nitrocellulose membranes. The membranes were washed with $\mathrm{PBS}$ and incubated at $4^{\circ} \mathrm{C}$ overnight under gentle agitation with each primary antibody: rat anti-CD74 (1: 500; BD PharMingen), rabbit anti-IFN- $\gamma$ (1: 1000; Life Technologies), goat anti-CatS (M-19, 1: 1000; Santa Cruz Biotechnology), goat anti-Cyst C (1: 1000; R\&D Systems), goat anti-cleaved IL- $1 \beta$ (m118, 1:500; Santa Cruz Biotechnology), rabbit anti-phospho-p38 MAPK (1:1000; Cell Signaling Technology), rabbit anti-p38 MAPK (1: 1000; Cell Signaling Technology), or mouse anti-actin (1:5000; Abcam). After being washed, the membranes were incubated with horseradish peroxidase (HRP)-labeled anti-rat (1:2000; GE Healthcare), anti-goat (1:2000 R\&D Systems), anti-rabbit (1:2000; GE Healthcare), or antimouse (1:2000; GE Healthcare) antibodies for $2 \mathrm{~h}$ at room temperature. Subsequently, the membrane-bound, HRP-labeled antibodies were detected using an enhanced chemiluminescence detection system (ECK lit; GE Healthcare) with an image analyzer (LAS-1000; Fuji Photo Film).

Flow cytometric analysis of $\mathrm{CD} 4^{+} T$-cell subsets. $\mathrm{CD} 4^{+} \mathrm{T}$-cells were isolated from splenocytes of DBA/2 and C57BL/ 6 mice at $14 \mathrm{~d}$ after subjected to peripheral nerve injury. Isolated cells were washed twice with FACS HANKS buffer and preincubated with an Fcg receptor blocking $\mathrm{mAb}$ (CD16/32; 2.4G2, clone:93) for $10 \mathrm{~min}$ at $4^{\circ} \mathrm{C}$. After CD4 staining (anti-CD4-

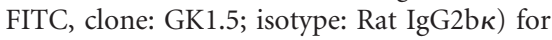
$20 \mathrm{~min}$ and the cells were then incubated with fixed Fixation Buffer and Permeabilization Wash Buffer (BioLegend) for $20 \mathrm{~min}$ at $24^{\circ} \mathrm{C}$. Fixed/permeabilized cells were then washed twice with wash buffer and then incubated with anti-IFN-g-APC (clone: XMG1.2; isotype: Rat IgG1 $\kappa$ ), anti-IL-17-PE (clone: TC11-18H10.1; isotype: Rat $\operatorname{IgG} 1 \kappa$ ), and anti-Foxp3-PE (clone: MF-14; isotype: Rat IgG2b $\kappa$ ) for $20 \min$ at $4^{\circ} \mathrm{C}$. The stained cells were washed twice with FACS Hanks buffer, and were analyzed by using FACSVerse flow cytometer (BD Bioscience) using FACSuite software (BD Bioscience). All of the antibodies were purchased from BioLegend.

Data analysis. The data are presented as the rabbit anti-IFN- $\gamma(1: 1000)$, rabbit anti-CD11c (1:500; Bioss) with goat anti-CatS (1:500) for $2 \mathrm{~d}$ at $4^{\circ} \mathrm{C}$. The sections were washed with PBS and incubated with a mixture of secondary antibodies conjugated with donkey anti-rabbit AlexaFluor 488 (1:400), donkey anti-rat Cy3 (1: $400)$, donkey anti-rabbit Cy3 (1:400), and donkey anti-goat AlexaFluor $488(1: 400)$ for $3 \mathrm{~h}$ at $24^{\circ} \mathrm{C}$. The sections were washed with PBS and mounted in the anti-fading medium Vectashield (Vector Laboratories), and examined with a confocal laser-scanning microscope (CLSM; 2si Confocal Laser Microscope, Nikon) using a $20 \times$ objective (numerical aperture $=0.75$ ) or $60 \times$ oil-immersion objective (numerical aperture $=$ 1.40). The Iba1-positive cells in the spinal dorsal horn and the CD4-, IFN- $\gamma$-, CD11c-, and CatS-positive cells in the spleen were counted and normalized by $0.15 \mathrm{~mm}^{2}$.

Immunoblot analyses. Mice were transcardially perfused with PBS, then the spleen and L4 spinal cord tissues were removed 1, 3, 7, or $14 \mathrm{~d}$ after peripheral nerve injury. The specimens were quickly frozen and stored at $-80^{\circ} \mathrm{C}$ until they were used. The immunoblot analyses were means \pm SEM. The statistical analyses of the results were performed with Student's unpaired $t$ tests, one-way ANOVAs with post hoc Tukey's tests, or two-way repeated-measures ANOVAs using the GraphPad Prism software package. A value of $p<0.05$ was considered to indicate statistical significance.

\section{Results}

Inhibition of neuropathic pain by the pharmacological blockade or genetic deletion of CatS

The involvement of CatS in the development of neuropathic tactile allodynia was examined by inhibiting CatS activity, either through a genetic deletion or by pharmacological means. A significant decrease in the paw withdrawal threshold (PWT) was observed from $1 \mathrm{~d}$ after peripheral nerve injury in the vehicle group, indicating the development of neuropathic tactile allo- 


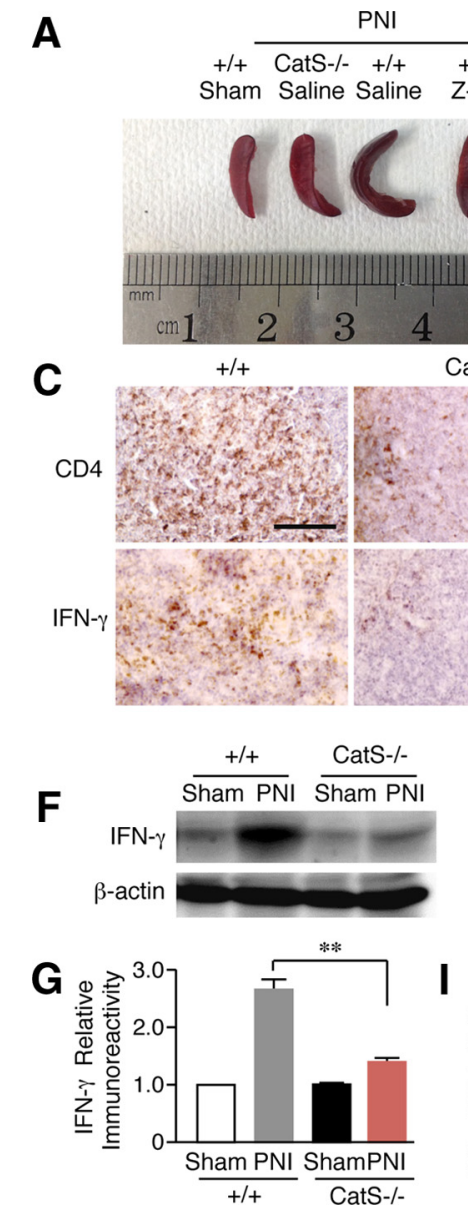

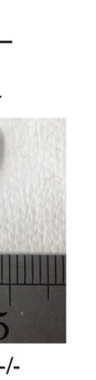

CatS-/-

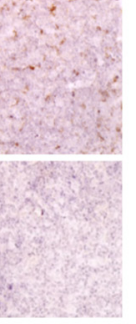

B

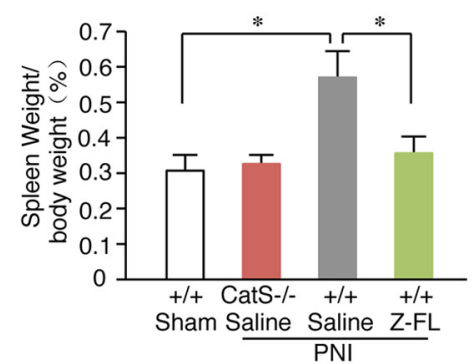

D
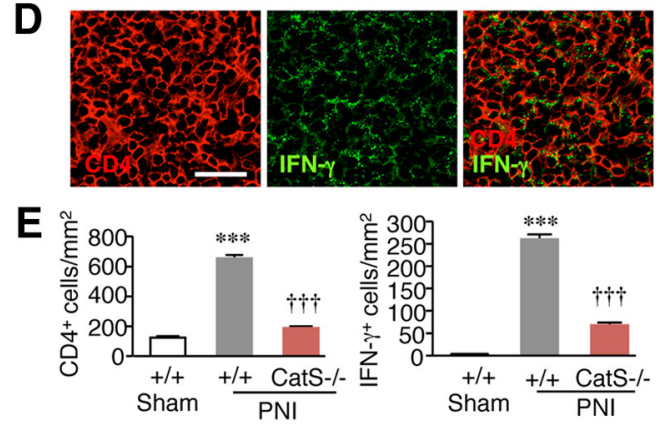

H
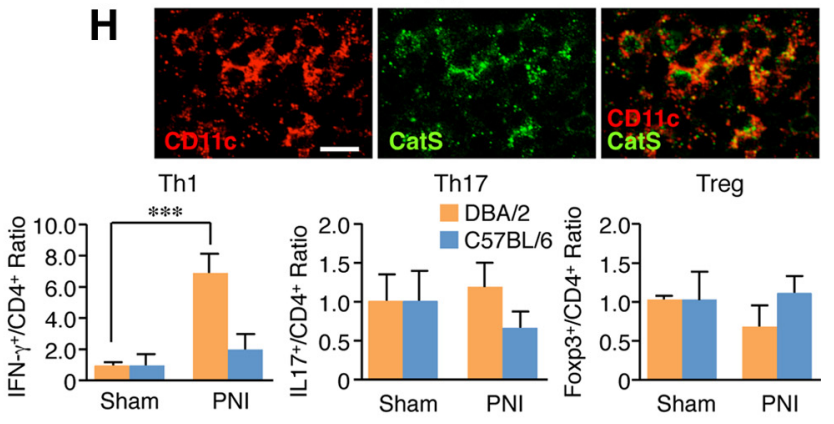

Figure 2. The inhibitory effects of the genetic deletion and pharmacological inhibition of Cat $S$ on the increase number of splenocytes following PNI. $A$, The suppression of the PNI-induced splenic hypertrophy following PNI by the genetic deletion and pharmacological inhibition of CatS. B. The mean spleen weight per body weight in wild-type mice, CatS ${ }^{-1-}$ mice and wild-type mice administered Z-FL (i.p.) $14 \mathrm{~d}$ after PNI. Each column and vertical bar represents the mean \pm SEM of four independent experiments for each time point. Asterisks indicate a statistically significant difference between the values $\left({ }^{*} p<0.05\right)$. C, The immunoreactivities for CD4 and IFN- $\gamma$ in the spleens of wild-type or CatS ${ }^{-1-}$ mice $14 \mathrm{~d}$ after PNI. Scale bar, $200 \mu \mathrm{m}$. D, The immunofluorescent CLSM images for CD4, IFN- $\gamma$, and their merged images in the spleens of wild-type mice $14 \mathrm{~d}$ after PNI. Scale bar, $100 \mu \mathrm{m}$. $\boldsymbol{E}$, The mean number of CD4- (D) or IFN- $\gamma$-positive cells in sham-operated wild-type mice, wild-type mice and $\mathrm{CatS}^{-1-}$ mice $14 \mathrm{~d}$ after PNI. Each column and vertical bar represents the mean \pm SEM of three independent experiments for each time point. The asterisks indicate a statistically significant difference from the sham-operated wild-type mice $\left.{ }^{* * *} p<0.001\right)$. Daggers indicate a statistically significant difference from the nerve-injured wild-type mice $(\dagger+t p<0.001) . F$, The results of the immunoblot analyses of IFN- $\gamma$ in the spleens of wild-type and Cat ${ }^{-1-}$ mice $14 \mathrm{~d}$ after PNI. G, The mean protein level of IFN- $\gamma$ in the spleens of sham-operated, wild-type mice or $\mathrm{CatS}^{-1-}$ mice $14 \mathrm{~d}$ after PNI. Each column and vertical bar represents the mean \pm SEM of three independent experiments for each time point. Aterisks indicate a statistically significant difference between the values $\left({ }^{* *} p<0.01\right)$. $\boldsymbol{H}$, The immunofluorescent CLSM images for CD11c, CatS, and their merged images in the spleens of wild-type mice $14 \mathrm{~d}$ after PNI. Scale bar, $20 \mu \mathrm{m}$. I, The mean ratios of IFN- $\gamma^{+} \mathrm{CD} 4{ }^{+}$T-cells (Th1 cells), IL- $17^{+}{ }^{C D} 4^{+}$T cells (Th17 cells), and Foxp3 ${ }^{+}$CD4 ${ }^{+}$T-cells (Treg cells) within the total CD4 ${ }^{+}$T-cells in the spleens of at $14 \mathrm{~d}$ after PNI. Asterisks indicate a statistically significant difference between the values $\left({ }^{* *} p<0.001\right)$.

dynia. In CatS ${ }^{-1-}$ mice, the mean PWT was also decreased for up to $2 \mathrm{~d}$ after peripheral nerve injury to the same extent as in wild-type mice (Fig. 1A). However, no further significant decrease in the mean PWT was observed in $\mathrm{CatS}^{-1-}$ mice $3 \mathrm{~d}$ after peripheral nerve injury. On the other hand, daily administration of Z-FL ( $10 \mu \mathrm{g} / 10 \mathrm{~g}$, i.p.), a specific inhibitor of CatS, from 5 to $14 \mathrm{~d}$ after peripheral nerve injury significantly reversed the established tactile allodynia (Fig. $1 B$ ). It was also noted that the daily administration of Z-FL over $14 \mathrm{~d}$ from the day of peripheral nerve injury inhibited the decrease in PTW from $6 \mathrm{~d}$ after peripheral nerve injury.

These observations suggest that the peripheral enzymatic activity of CatS plays an essential role in the maintenance of neuropathic pain following peripheral nerve injury. It has been considered that Cat $S$ is involved in the peripheral nerve injury-induced activation of $\mathrm{T}$-cells through antigen presentation, because Cat $\mathrm{S}$ is required for the final cleavage step of Ii in antigen presenting cells. Both the spleen and the lymph nodes are the secondary lymphoid organs, which initiate adaptive immune responses. In our preliminary experi- ments, we found that the numbers of $\mathrm{CD} 4{ }^{+} \mathrm{T}$-cells isolated from the spleen and lumber lymph node, the lymphatic drainage of the lumbar nerves (Cao and Deleo, 2008; van Zwam et al., 2009), after peripheral nerve injury were $2 \times 10^{7}$ and $1 \times 10^{5}$, respectively. Therefore, we focused on the spleen as the secondary lymphoid organs in the present study, because the peripheral nerve injury increased the number of $\mathrm{CD} 4^{+} \mathrm{T}$-cells in the spleen $\sim 200$-fold in comparison with that in the lumber lymph nodes. To determine the contribution of the spleen to the development of neuropathic tactile allodynia, we compared the PWT of splenectomized and sham-operated mice following peripheral nerve injury. The peripheral nerve injury-induced decrease in the PWT was significantly attenuated in splenectomized mice (Fig. 1C).

\section{Possible peripheral roles of CatS in neuropathic pain}

Peripheral nerve injury induces increased number of splenocytes, which is associated with immunological reactions. Therefore, we 
A
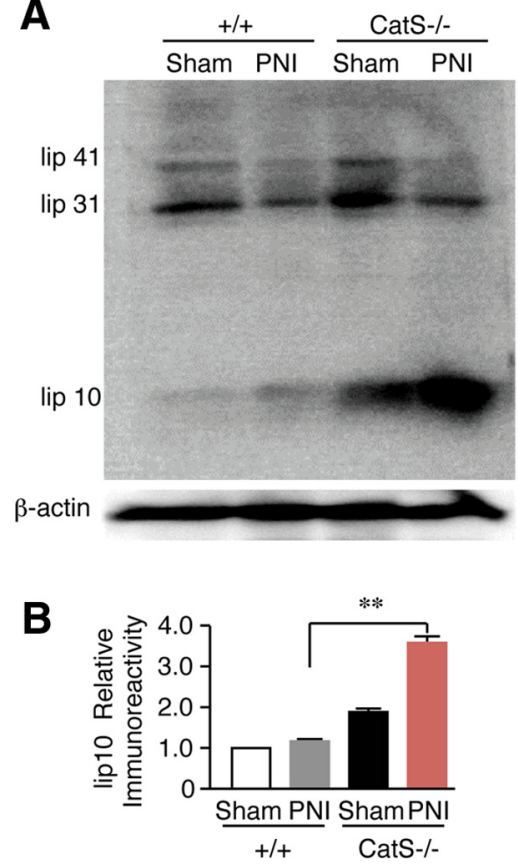

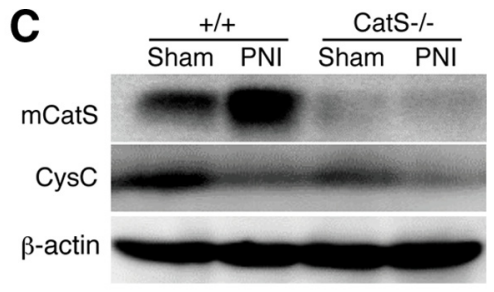

D

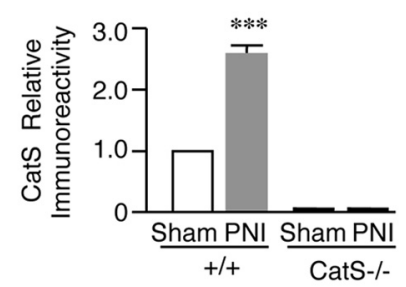

E

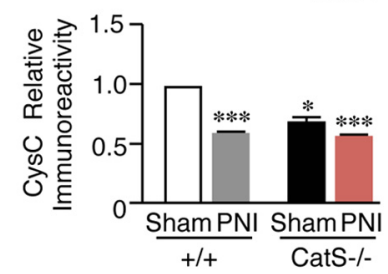

Figure 3. The results of the immunoblot analyses of lip 10 , CatS, and Cys $\mathrm{C}$ in the spleens of wild-type and $\mathrm{CatS}^{-\prime-}$ mice. $\boldsymbol{A}$, The accumulation of lip 10 in the spleens of sham-operated, wild-type mice or $\mathrm{CatS}^{-1-}$ mice $14 \mathrm{~d}$ after PNI. $\boldsymbol{B}$, The mean protein levels of lip10 in the spleens of sham-operated, wild-type or CatS ${ }^{-1-}$ mice $14 \mathrm{~d}$ after PNI. Each column and vertical bar represents the mean \pm SEM of three independent experiments for each time point. Asterisks indicate a statistically significant difference between the values $\left({ }^{* *} p<0.01\right)$. C, The changes in the levels of Cat $S$ and Cys $C$ in the spleens of sham-operated, wild-type mice or $\mathrm{CatS}^{-1-}$ mice $14 \mathrm{~d}$ after PNI. The mean protein levels of mature $\mathrm{Cat} S(\boldsymbol{D})$ and $\mathrm{Cys} \boldsymbol{C}(\boldsymbol{E})$ in the spleens of sham-operated, wild-type or CatS ${ }^{-1-}$ mice $14 \mathrm{~d}$ after PNI. Each column and vertical bar represents the mean \pm SEM of three independent experiments for each time point. Asterisks indicate a statistically significant difference from sham-operated wild-type mice $(* * p<0.01)$.

next examined the possible involvement of CatS in the increased number of splenocytes and activation of T-cells following peripheral nerve injury. CatS deficiency or the pharmacological inhibition of CatS significantly suppressed increase in splenocytes $14 \mathrm{~d}$ after peripheral nerve injury (Figs. $2 A, B$ ). The immunoreactivities for CD4 and IFN- $\gamma$ were significantly increased in the splenic white pulp after peripheral nerve injury, indicating the activation of Th1 cells in the spleen after peripheral nerve injury (Figs. 2C$E)$. The immunoreactivity for IFN- $\gamma$ corresponded well with that for $\mathrm{CD} 4$ (Fig. 2D). The mean percentage of splenic $\mathrm{CD} 4{ }^{+} \mathrm{T}$-cells expressing IFN- $\gamma$ was $49.7 \pm 2.9 \%(n=3)$ of mice subjected to peripheral nerve injury. On the other hand, there was no $\mathrm{CD} 4{ }^{+}$ T-cell expressing IFN- $\gamma$ in the spleen of sham-operated mice. The peripheral nerve injury-induced increase in the immunoreactivities for CD4 and IFN- $\gamma$ in the splenic white pulp was significantly reduced in $\mathrm{CatS}^{-1-}$ mice compared with wild-type mice (Figs. 2E). The peripheral nerve injury-induced increase in the mean protein level of IFN- $\gamma$ in the spleen was also significantly reduced in $\mathrm{CatS}^{-1-}$ mice (Fig. $2 F, G$ ). The mean percentage of CatS-positive $\mathrm{CD} 11 \mathrm{c}^{+}$dendritic cells in the spleen of mice subjected to peripheral nerve injury was $83.5 \pm 4.6 \%(n=3$; Fig. $2 \mathrm{H}$ ). On the other hand, CatS-positive $\mathrm{CD}_{11 \mathrm{~b}}{ }^{+}$macrophages in the spleen of mice subjected to peripheral nerve injury was $19.7 \pm$ $1.8 \%(n=3)$.

It was also noted that splenic hypertrophy was not observed in C57BL/6 mice following peripheral nerve injury. In C57BL/6 mice, the mean spleen weight/body weight was not significantly different between sham mice $(0.55 \pm 0.14 \%, n=3)$ and mice subjected to peripheral nerve injury $(0.34 \pm 0.04 \%, n=3)$. To further clarify strain difference of peripheral immune responses between DBA/2 and C57BL/6 mice, possible change of $\mathrm{CD} 4^{+}$
T-cell subsets in the spleen of these two inbred mouse strains following peripheral nerve injury was examined using flow cytometric analysis. The mean proportion of $\mathrm{IFN}_{-\mathrm{g}}{ }^{+} \mathrm{CD} 4^{+}$T-cells (Th1 cells) within the total $\mathrm{CD} 4^{+}$T-cells was increased by 6.8 times in the spleens of $\mathrm{DBA} / 2$ mice following peripheral nerve injury (Fig. 2I). This result is consistent with the immunohistochemical observation. In contrast, their mean proportion was not changed in C57BL/6 mice following peripheral nerve injury. On the other hand, the mean proportion of either IL$17^{+} \mathrm{CD} 4^{+}$T-cells (Th17 cells) or Foxp $3{ }^{+} \mathrm{CD} 4{ }^{+}$T-cells (Treg cells) within the total $\mathrm{CD}^{+}{ }^{+} \mathrm{T}$-cells was not significantly changed following peripheral nerve injury in the spleen of these two inbred mouse strains (Fig. 2I). Therefore, peripheral nerve injury induces the CatSdependent antigen-specific the activation of the splenic Th1 cells in DBA/2, but not in C57BL/6, mice. Furthermore, the mean number of $\mathrm{CD} 3^{+} \mathrm{T}$-cells was significantly increased in the ipsilateral dorsal spinal cord of DBA/2 mice following peripheral nerve injury. In contrast, the infiltration of $\mathrm{CD} 4{ }^{+} \mathrm{T}$-cells was not detected in the dorsal spinal cord of C57BL/6 mice following peripheral nerve injury (data not shown). These observations strongly suggest the strain difference of peripheral immune responses following peripheral nerve injury.

Accumulation of lip10 in the spleens of neuropathic $\mathrm{CatS}^{-/-}$mice The inhibition of CatS halts the processing of Ii at a stage referred to as lip10, a fragment corresponding to the $\sim 100$ amino-acids residues of Ii. To further clarify the involvement of CatS in the activation of the $\mathrm{CD} 4^{+} \mathrm{T}$-cells, the mean protein level of lip10 in the spleen was compared between wild-type and $\mathrm{CatS}^{-1-}$ mice following peripheral nerve injury. Only slight accumulation of lip10 was observed in either sham or nerve-injured wild-type mice (Figs. $3 A, B$ ). In $\mathrm{CatS}^{-1-}$ mice, however, there was a marked accumulation of lip10 in the spleen and the mean level was further significantly increased after peripheral nerve injury (Figs. $3 A, B)$. The mean protein level of mature CatS was significantly increased (Figs. $3 C, D$ ), whereas that of $C y s C$ was significantly decreased following peripheral nerve injury (Figs. 3C,E). In $\mathrm{CatS}^{-1-}$ mice, the mean protein level of CysC was significantly lower than that of wild-type mice, and the mean level was not significantly changed following peripheral nerve injury (Figs. $3 C, E)$.

\section{Enhancement of tactile allodynia by the adoptive transfer of splenic CD4 ${ }^{+}$T-cells}

To further analyze the involvement of CatS in functional CD4 ${ }^{+}$ T-cell-dependent responses involved in the maintenance of neuropathic tactile allodynia, splenocyte cell subpopulations prepared from neuropathic animals were systemically injected into mice subjected to peripheral nerve injury. When intraperitoneal injection of splenocytes prepared from neuropathic wild-type mice were conducted $5 \mathrm{~d}$ after peripheral nerve injury, their mean 
A

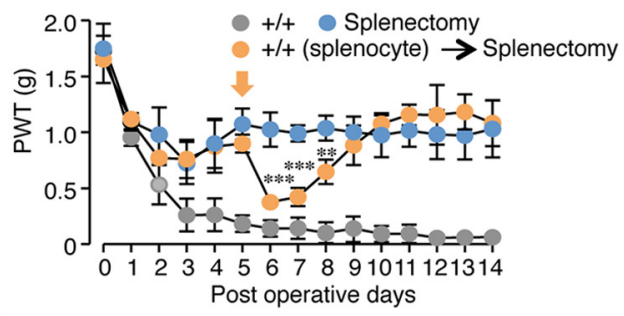

C

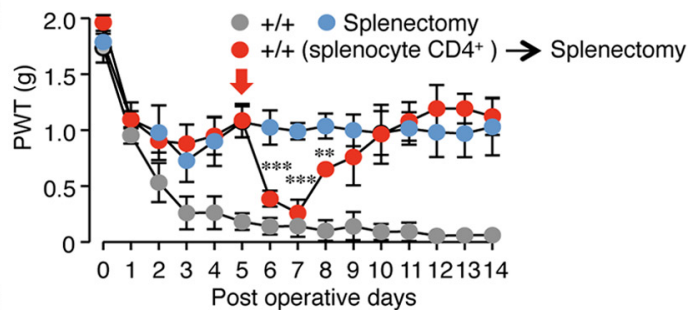

E

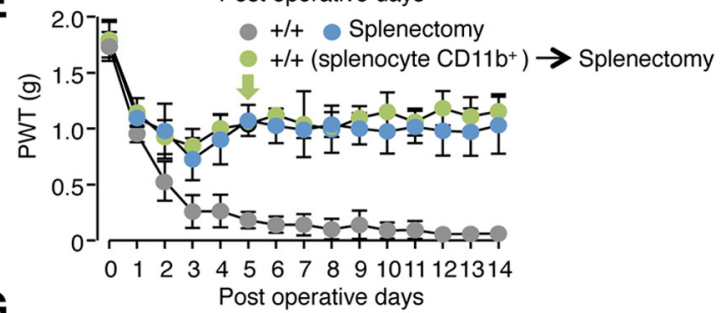

G

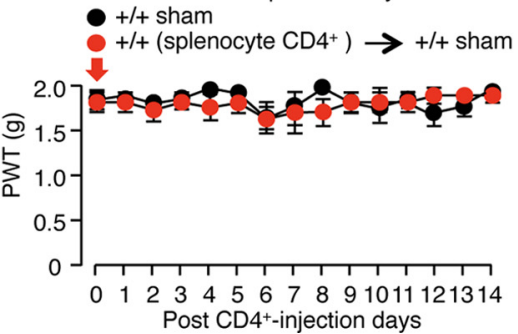

B

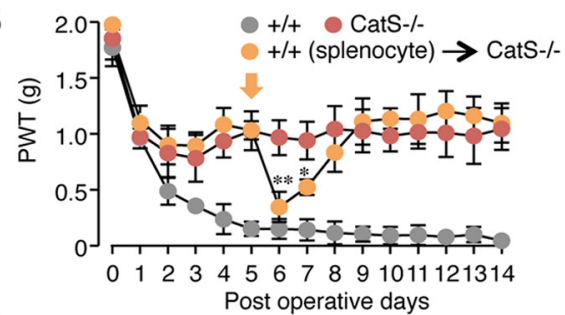

D

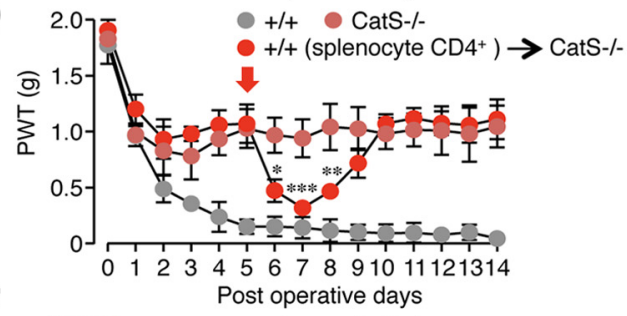

F

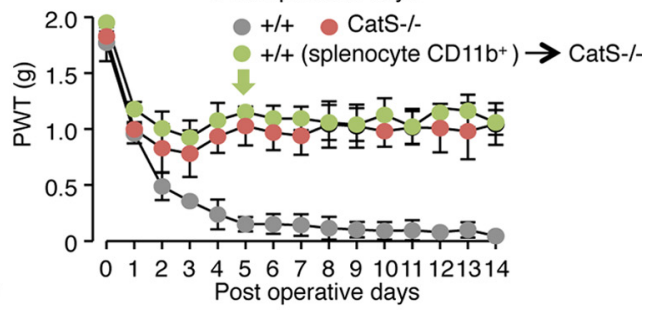

H

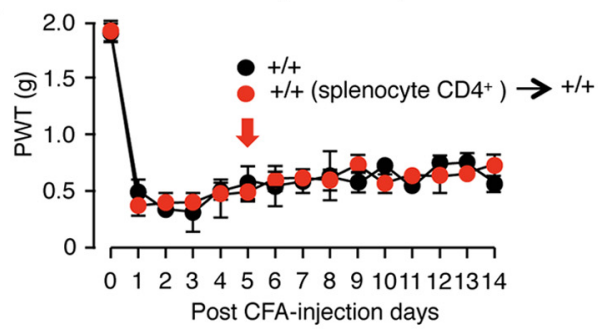

Figure 4. The critical involvement of the spleens in the development of neuropathic tactile allodynia. $A, B$, The adoptive transfer of splenocytes prepared from the neuropathic wild-type mice induced a significant decline of the PWT in the splenectomized wild-type mice $(\boldsymbol{A})$ or CatS $^{-1-}$ mice $(\boldsymbol{B})$ subjected to PNI. Each symbol and vertical bar represents the mean \pm SEM of five independent experiments. Asterisks indicate a statistically significant difference between the splenectomized wild-type mice $(\boldsymbol{A})$ or $\mathrm{Cat}^{-1-}$ mice $(\boldsymbol{B})$ subjected to PNI $\left({ }^{*} p<0.05\right.$, ${ }^{* *} p<0.01$, $\left.{ }^{* * *} p<0.001\right) . C, D$, The adoptive transfer of splenic $C 4^{+} T$-cells prepared from the neuropathic wild-type mice induced a significant decline of the PWT in the splenectomized wild-type mice $(\boldsymbol{C})$ or CatS ${ }^{-1-}$ mice $(\boldsymbol{D})$ subjected to PNI. Each symbol and vertical bar represents the mean \pm SEM of five independent experiments. Asterisks indicate a statistically significant difference between the splenectomized wild-type mice $(\boldsymbol{C})$ and CatS ${ }^{-1-}$ mice $(\boldsymbol{D})$ subjected to PNI $\left({ }^{*} p<0.05,{ }^{* *} p<0.01,{ }^{* * *} p<0.001\right)$. $\boldsymbol{E}$, $\boldsymbol{F}$, The adoptive transfer of splenic CD11b ${ }^{+}$monocytes/macrophages prepared from the neuropathic wild-type mice induced no significant changes of the PWT in the splenectomized wild-type mice $(\boldsymbol{E})$ or $\mathrm{CatS}^{-1-}$ mice $(\boldsymbol{F})$ subjected to PNI. Each symbol and vertical bar represents the mean \pm SEM of four independent experiments. $\mathbf{G}$, The adoptive transfer of splenic $C D 4^{+}$T-cells prepared from the neuropathic wild-type mice failed to induce tactile allodynia in the sham-operated wild-type mice. Each symbol and vertical bar represents the mean \pm SEM of four independent experiments. $\boldsymbol{H}$, The adoptive transfer of splenic CD4 ${ }^{+} \mathrm{T}$-cells prepared from the neuropathic wild-type mice failed to induce a significant change of the PWT in CFA-induced inflammatory mice. Each symbol and vertical bar represents the mean \pm SEM of four independent experiments.

levels of neuropathic tactile allodynia in the mice were significantly enhanced for 2-3 d in splenectomized wild-type mice (Fig. $4 A$ ) or CatS $^{-1-}$ mice (Figs. $4 B$ ). A similar enhancement of the mean levels of neuropathic tactile allodynia was also observed after a single injection of splenic CD4 ${ }^{+} \mathrm{T}$-cells prepared from neuropathic wild-type mice into splenectomized wild-type mice (Fig. 4C) or CatS ${ }^{-1-}$ mice (Fig. 4D). In contrast, when monocytes/macrophages prepared from the splenocytes of neuropathic wild-type mice were injected into splenectomized wild-type mice or CatS ${ }^{-1-}$ mice, no significant change was observed in the mean level of neuropathic tactile allodynia (Figs. $4 E, F$ ). When splenic $\mathrm{CD}^{+}{ }^{+} \mathrm{T}$-cells prepared from neuropathic wild-type mice were injected to sham wild-type mice, no significant change of PWT was observed (Fig. 4G). Furthermore, injection of splenic CD4 ${ }^{+}$ $\mathrm{T}$-cells prepared from neuropathic wild-type mice failed to enhance tactile allodynia observed in the CFA-induced inflammatory pain mice (Fig. $4 H$ ). These results suggest that CatS is involved in the $\mathrm{CD} 4{ }^{+}$T-cell-dependent responses, which play essential roles in the maintenance of neuropathic pain.

\section{Interaction of activated $\mathrm{CD} 4{ }^{+} \mathrm{T}$-cells and microglia in the dorsal spinal cord}

To determine the effects of CatS in the infiltration of T-cells in the dorsal spinal cord following peripheral nerve injury, immunohistochemical staining using anti-CD3 and anti-IFN- $\gamma$ antibodies was conducted. The mean number of $\mathrm{CD}^{+}{ }^{+} \mathrm{T}$-cells was significantly increased in the ipsilateral dorsal spinal cord following peripheral nerve injury. Approximately $80 \%$ of the $\mathrm{CD} 3{ }^{+} \mathrm{T}$-cells were found to express IFN- $\gamma$ (Fig. 5A). CatS deficiency and Z-FL treatment both significantly decreased the mean number of $\mathrm{CD}^{+}{ }^{+} \mathrm{T}$-cells in the ipsilateral dorsal spinal cord of wild-type mice $14 \mathrm{~d}$ after peripheral nerve injury (Fig. $5 B$ ). Furthermore, the immunoreactivity for pSTAT1, a molecule downstream of IFN- $\gamma$ receptor activation, was markedly increased in exclusively 
A
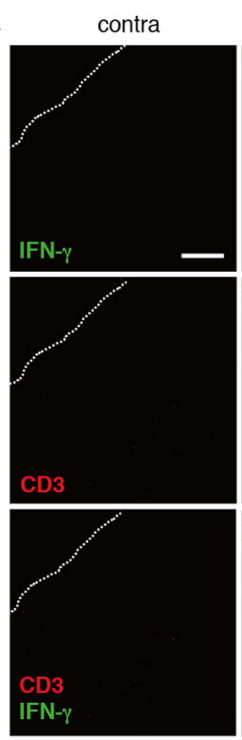

B

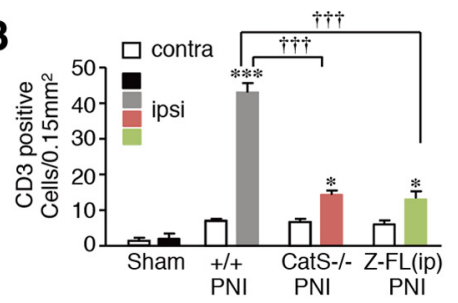

C
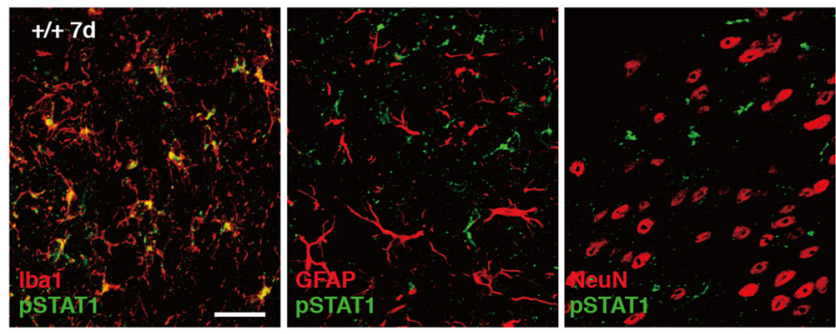

ipsi
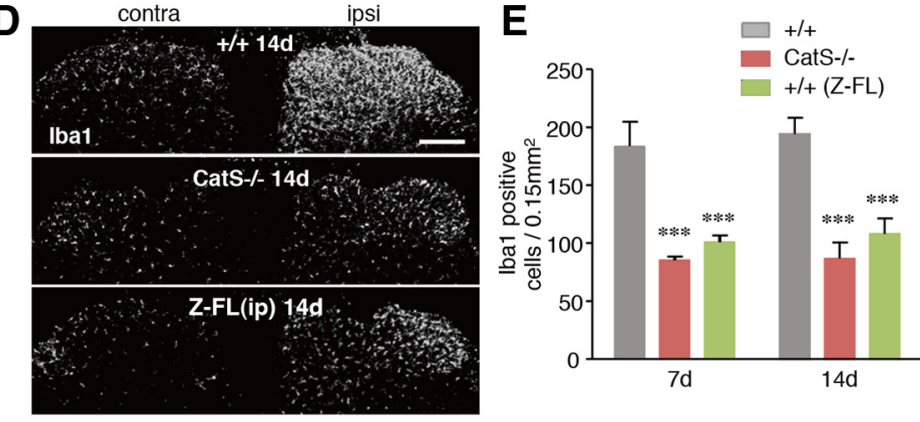

$\mathbf{F}$

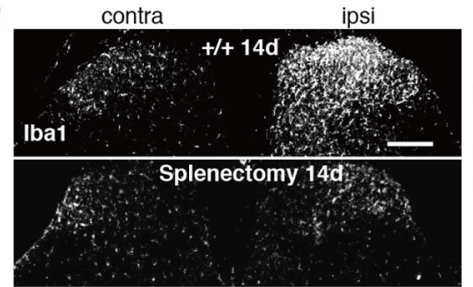

Figure 5. The inhibitory effects of CatS deficiency on the PNI-induced infiltration of Th1 T-cells in the dorsal spinal cord and the proliferation of spinal microglia. $A$, CLSM images for CD3 and IFN- $\gamma$ immunoreactivities in the ipsilateral dorsal spinal cord of wild-type mice $14 \mathrm{~d}$ after PNI. Scale bar, $100 \mu \mathrm{m}$. Insets, Higher-power micrographs showing examples of CD3 ${ }^{+}{ }^{-}$-cells expressing IFN- $\gamma$. Scale bar, $50 \mu \mathrm{m} . \boldsymbol{B}$, The mean number of CD3-positive T-cells in the ipsilateral dorsal spinal cord in sham-operated, wild-type CatS $^{-1-}$, and Z-FL-treated wild-type mice 7 and $14 \mathrm{~d}$ after PNI. Each column and vertical bar represents the mean \pm SEM of three independent experiments for each time point. Asterisks indicate a statistically significant difference from the contra $\left({ }^{*} p<0.05\right.$, ${ }^{* * *} p<$ 0.001). Daggers indicate a statistically significant difference between the values ( $\mathrm{t}+t p<0.001)$. C, The immunofluorescent CLSM images for pSTAT1 merged with those of Ibal, GFAP, or NeuN in the ipsilateral dorsal spinal cord in wild-type mice $7 \mathrm{~d}$ after PNI. Scale bar, $40 \mu \mathrm{m}$. D. The immunofluorescent CLSM images for Iba1 in the ipsilateral dorsal spinal cord of wild-type mice, CatS ${ }^{-1-}$ mice, and Z-FL-treated wild-type mice $14 \mathrm{~d}$ after PNI. Scale bar, $1 \mathrm{~mm}$. E, The mean number of Iba1-positive microglia in the ipsilateral dorsal spinal cord in wild-type mice, CatS ${ }^{-1-}$ mice, and Z-FL-treated $+/+$ mice 7 and $14 \mathrm{~d}$ after PNI. Each column and vertical bar represents the mean \pm SEM of three independent experiments for each time point. Asterisks indicate a statistically significant difference from the wild-type mice $\left({ }^{* * *} p<0.001\right)$. $\boldsymbol{F}$, The immunofluorescent CLSM images for Iba1 in the dorsal spinal cord of the sham-operated and splenectomized wild-type mice $14 \mathrm{~d}$ after PNI. Scale bar, 1 $\mathrm{mm}$. G, The mean number of Iba1-positive microglia in the ipsilateral and contralateral dorsal spinal cord $14 \mathrm{~d}$ after PNI in sham-operated and splenectomized mice. Each column and vertical bar represents the mean \pm SEM of three independent experiments for each time point. Asterisks indicate a statistically significant difference between the values $\left({ }^{* * *} p<0.001\right)$.

Iba1-positive microglia in the wild-type mice following peripheral nerve injury (Fig. 5C), but not in either CatS ${ }^{-1-}$ or Z-FL-treated wild-type mice (data not shown). The mean ratio of Iba1-positive microglia that expressed pSTAT1 in the ipsilateral dorsal spinal cord of wild-type mice $7 \mathrm{~d}$ after peripheral nerve injury (65.4\%, $n=4)$ was significantly larger than that $3 \mathrm{~d}$ after injury $(3.4 \%$, $n=4 ; p<0.001)$.

These observations suggest that the infiltrated T-cell-derived IFN- $\gamma$ is associated with the proliferation of microglia in the ipsilateral dorsal spinal cord in the maintenance phase of neuropathic pain. The effects of CatS deficiency and Z-FL on the proliferation of microglia in the dorsal spinal cord were therefore examined following peripheral nerve injury. CatS deficiency and Z-FL treatment both significantly reduced the mean number of Iba1-positive microglia in the ipsilateral dorsal spinal cord 7 and $14 \mathrm{~d}$ after peripheral nerve injury (Figs. 5D,E). Furthermore, the mean number of Iba1-positive microglia in the ipsilateral dorsal spinal cord was also significantly decreased in the splenectomized mice $14 \mathrm{~d}$ after peripheral nerve injury (Figs. $5 F, G$ ).

\section{Possible central roles of CatS in neuropathic pain}

To further elucidate a possible central role of CatS in neuropathic pain, the protein levels of CatS and CysC in the spinal cord were further examined in sham and nerve-injured mice. The mean protein level of mature CatS was significantly increased following peripheral nerve injury (Figs. $6 A-C$ ). On the other hand, the level of $\mathrm{Cys} C$ was not significantly changed following peripheral nerve injury (Figs. 6A-C). Increased immunoreactivity for CatS was exclusively observed in microglia, but not either neurons or astrocytes (Figs. $6 D, E$ ). In contrast, immunoreactivity for CysC was observed mainly in astrocytes and partially in microglia, but not in neurons (Fig. 6E). Furthermore, the mean levels of p-p38 MAPK and mature IL- $1 \beta$ significantly increased in wild-type mice, but not in $\mathrm{CatS}^{-1-}$ mice (Figs. $6 \mathrm{~F}-H$ ).

\section{Discussion}

We investigated a possible peripheral role of CatS in the maintenance of neuropathic pain, because CatS plays an essential role in the activation of $\mathrm{CD}_{4}{ }^{+} \mathrm{T}$-cells through the proteolytic degradation of lip10, which is required for MHCII molecules to bind to the antigenic peptide in antigen-presenting cells, including dendritic cells (Driessen et al., 1999; Riese et al., 2001). We herein showed for the first time that inhibition of CatS activity, either through genetic deletion or via a pharmacological inhibitor, significantly attenuated the maintenance of tactile allodynia, splenic hypertrophy, the increased cell number of splenic $\mathrm{CD} 4^{+} \mathrm{T}$-cells 
A

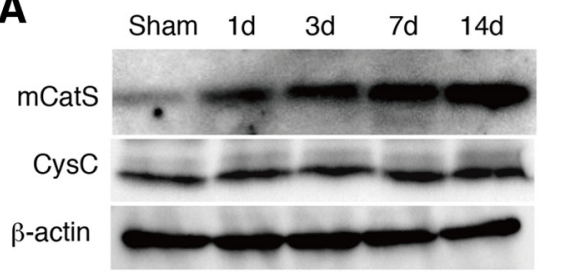

D
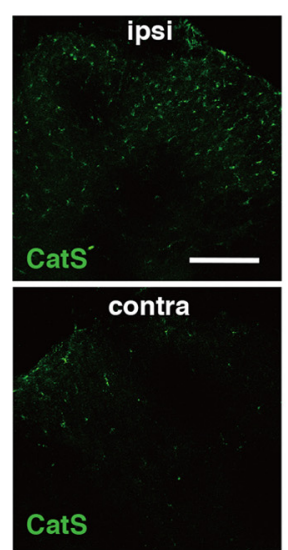

F

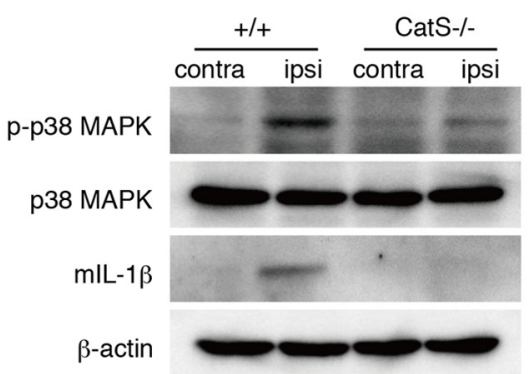

E
B
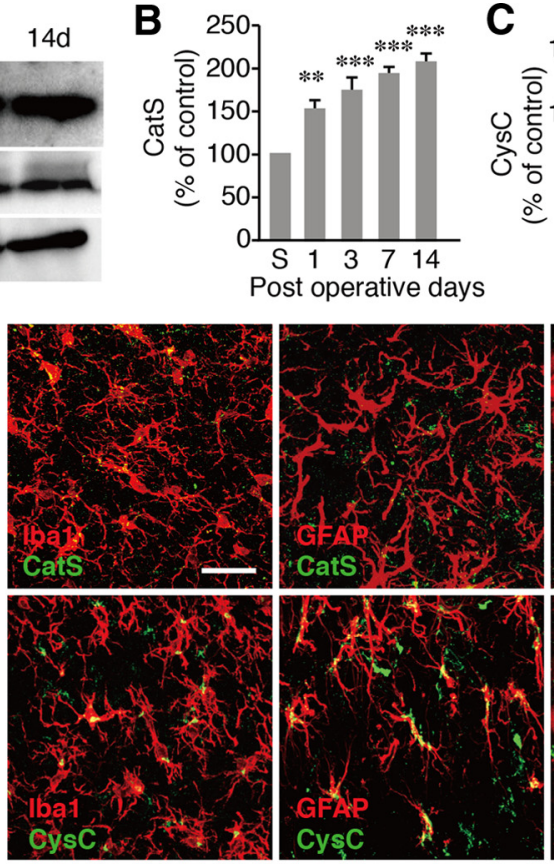

G

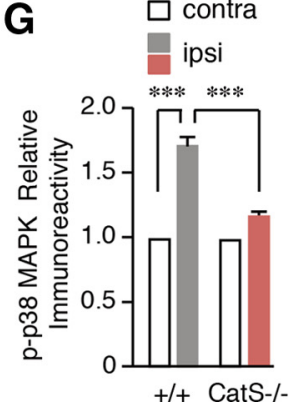

C
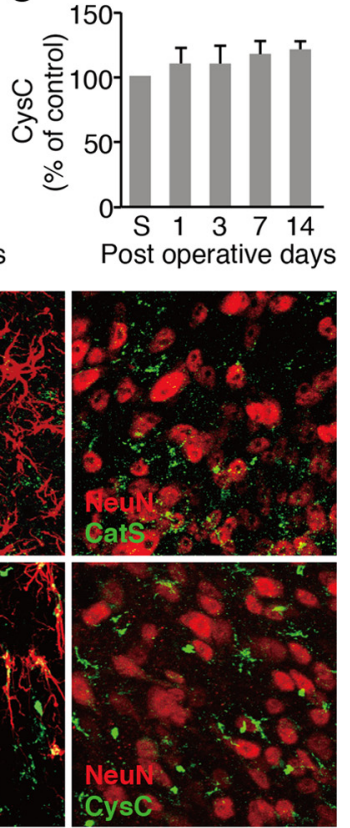

H

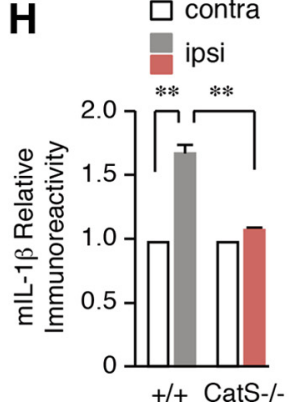

Figure 6. The inhibition of the activation of spinal microglia in $\mathrm{CatS}^{-1-}$ mice in induction phase of neuropathic pain. $A$, Results of the immunoblot analyses of mature CatS and CysC in the ipsilateral dorsal spinal cord after PNI. $\boldsymbol{B}, \boldsymbol{C}$, The mean levels of $\mathrm{mCatS}(\boldsymbol{B})$ and $\mathrm{CyS} C(\boldsymbol{C})$ in the spinal cord. Each column and vertical bar represents the mean \pm SEM of three independent experiments. Asterisks indicate a statistically significant difference from sham $(s)$ mice $\left({ }^{* *} p<0.01,{ }^{* * *} p<0.001\right)$. D. The immunofluorescent CLSM images for CatS in the ipsilateral and contralateral dorsal spinal cord of wild-type mice $3 \mathrm{~d}$ after PNI. Scale bar, $200 \mu \mathrm{m}$. E, The immunofluorescent CLSM images for CatS (top columns) and CysC (bottom columns) merged with those of Iba1, GFAP, or NeuN in the dorsal spinal cord of wild-type mice $3 \mathrm{~d}$ after PNI. Scale bar, $50 \mu \mathrm{m}$. $\boldsymbol{F}$, The results of immunoblot analyses of p-p38 and mature IL- $1 \beta$ in the ipsilateral dorsal spinal cord of wild-type and $\mathrm{CatS}^{-1-}$ mice $3 \mathrm{~d}$ after PNI. $\mathbf{G}, \boldsymbol{H}$, The mean levels of p-p38 MAPK $(\boldsymbol{G})$ and mature IL-1 $\beta(\boldsymbol{H})$ in the spinal cord of wild-type and $\mathrm{CatS}^{-1-}$ mice $3 \mathrm{~d}$ after PNI. Each column and vertical bar represents the mean \pm SEM of three independent experiments. Asterisks indicate a statistically significant difference between the values $\left({ }^{* *} p<0.01,{ }^{* * *} p<0.001\right)$.

and the accumulation of lip10 following peripheral nerve injury. There are two possible explanations for the increased cell number of splenic $\mathrm{CD} 4^{+} \mathrm{T}$-cells following peripheral nerve injury: their proliferation in the spleen and/or infiltration from other lymphoid organs. The proliferation of splenic $\mathrm{CD}^{+}{ }^{+} \mathrm{T}$-cells following peripheral nerve injury is much likely explanation, because the peripheral nerve injury increased the number of $\mathrm{CD} 4{ }^{+}$ $\mathrm{T}$-cells in the spleen $\sim 200$-fold in comparison with that in the lumber lymph nodes (our preliminary observation). However, a possible infiltration of CD4 ${ }^{+} \mathrm{T}$-cells from other lymphoid organs including the lumber lymph node cannot be totally ruled out.

It was also noted that splenectomy significantly attenuated the maintenance of neuropathic tactile allodynia. Our observations showed that the level of CatS was significantly increased in the spleen following peripheral nerve injury, whereas the level of $\mathrm{CysC}$ was significantly decreased. This is consistent with the previous finding that the increase in Ii chain processing activity upon maturation of dendritic cells was not accompanied by an increased expression of CatS, but rather by decreased expression and altered localization of CysC (Pierre and Mellman, 1998). Although little is known about the antigens that contribute to the activation of $\mathrm{CD} 4{ }^{+} \mathrm{T}$-cells, some fragments of myelin basic protein can initiate tactile allodynia in both T-cell-dependent and -independent manners (Liu et al., 2012). Interestingly, injection of the splenic $\mathrm{CD}^{+}{ }^{+} \mathrm{T}$-cells prepared from neuropathic mice induced no significant change of PWT in sham wild-type mice and the CFA-induced inflammatory pain mice. All of these observations support the idea that peripheral role of CatS is necessary for the antigen-specific activation of $\mathrm{CD} 4{ }^{+} \mathrm{T}$-cells, which contributes to the transition of acute pain to a chronic state.

Moalem et al. (2004) demonstrated that the activation of Th1 cells is essential for neuropathic tactile allodynia. They clearly showed that the passive transfer of Th1 cells obtained from the spleens of neuropathic animals into neuropathic congenital athymic nude rats, which lack mature $\mathrm{T}$-cells, returns their pain levels to those of their heterozygous littermates (Moalem et al., 2004). In contrast, the transfer of Th2 cells has been shown to induce antinociceptive effects in heterozygous neuropathic rats. Our observations here also showed that the adoptive transfer of splenocytes or splenic $\mathrm{CD} 4{ }^{+} \mathrm{T}$-cells prepared from neuropathic mice significantly reduced the mean PWT for tactile allodynia in neuropathic splenectomized mice or $\mathrm{CatS}^{-1-}$ mice. A single transfer 
of $\mathrm{CD} 4{ }^{+} \mathrm{T}$-cells induced a significant reduction of the mean PTW for 2-3 d. Therefore, it is considered that a continuous infiltration of $\mathrm{CD} 4{ }^{+} \mathrm{T}$-cells is needed to establish a chronic state of neuropathic tactile allodynia. In this study, however, we found that there is a strain difference of peripheral immune responses following peripheral nerve injury. Our observations show that peripheral nerve injury induced splenic hypertrophy, increased population of splenic Th1 cells and their infiltration in the dorsal spinal cord in DBA/2, but not in C57BL/6, mice. Differential MHC haplotype antigens are responsible for differential immune responses of inbred mouse strains (McDevitt and Chinitz, 1969). $\mathrm{DBA} / 2$ and $\mathrm{C} 57 \mathrm{BL} / 6$ mice have differential MHC haplotype antigens, $\mathrm{H}-2^{\mathrm{d}}$ and $\mathrm{H}-2^{\mathrm{b}}$, respectively. Therefore, differential peripheral immune responses of DBA/2 and C57BL/6 mice following peripheral nerve injury may stem from their differential MHC haplotype antigens.

On the other hand, the infiltration of monocytic cells into the dorsal spinal cord is also thought to accelerate neuropathic pain. Zhang et al. (2007) first demonstrated that the infiltration of CCR2-positive monocytes has a key role in the development of neuropathic pain. Pharmacological inhibition of CCR2 and CCR5 also reduced the infiltration of monocytic cells into the dorsal spinal cord after peripheral nerve injury (Padi et al., 2012). However, the role of infiltrated monocytes in the development of neuropathic tactile allodynia is still a matter of controversy, because the major evidence supporting the importance of infiltrated monocytes came from the experiments using bone marrow transplantation following irradiation, which weakens the integrity of the blood-spinal cord barrier. In this study, the adoptive transfer of $\mathrm{CD}_{11 \mathrm{~b}^{+}}$monocytes/macrophages prepared from neuropathic wild-type mice into neuropathic splenectomized wild-type mice or CatS ${ }^{-1-}$ mice induced no changes in the pain level. Further studies will be necessary to clarify whether there is infiltration of monocytes/macrophages, and their roles in the development of neuropathic pain.

There is accumulating evidence that agents that have immunosuppressive and/or immunomodulatory properties significantly ameliorate neuropathic pain. The systemic administration of glatiramer acetate, a synthetic amino acid polymer used for alleviating the symptoms of multiple sclerosis, attenuates tactile allodynia following peripheral nerve injury (Leger et al., 2011). Furthermore, systemic treatment with a potent S1P agonist, FTY720 (Coste et al., 2008), or a CD28 superagonist that expands the regulatory T-cell population (Austin et al., 2012), also significantly improved established neuropathic pain (Coste et al., 2008; Austin et al., 2012). These observations strongly suggest that functional $\mathrm{CD} 4{ }^{+} \mathrm{T}$-cell-dependent responses play major roles in the maintenance of neuropathic pain.

Tsuda et al. (2009) reported that the level of activated STAT1, a molecule downstream of IFN- $\gamma$ receptors, was increased exclusively in microglia after the intrathecal injection of IFN- $\gamma$, which can strongly activate microglia (Hanisch and Ketenmann, 2007). Microglia are fully activated $3 \mathrm{~d}$ after peripheral nerve injury, whereas the level of IFN- $\gamma$ mRNA is significantly increased at $7 \mathrm{~d}$, but not $3 \mathrm{~d}$ (induction phase), after peripheral nerve injury (Costigan et al., 2009). Although the cellular source of IFN- $\gamma$ in the spinal cord has not yet been identified, the main possible cellular sources are infiltrated Th1 cells and partially activated microglia (Kawanokuchi et al., 2006). Furthermore, the peripheral nerve injury-induced tactile allodynia and activation of spinal microglia were significantly attenuated in IFN- $\gamma$ receptordeficient mice (Costigan et al., 2009; Tsuda et al., 2009). Consistent with these reports, our observations clearly indicate that
STAT1, a molecule downstream of IFN- $\gamma$ receptor activation, is significantly activated in microglia $7 \mathrm{~d}$, but only partially $3 \mathrm{~d}$, after peripheral nerve injury. In contrast, the peripheral nerve injuryinduced infiltration of CD4 ${ }^{+}$T-cells expressing IFN- $\gamma$ and the activation of STAT1 in spinal microglia were significantly attenuated in $\mathrm{CatS}^{-1-}$ or Z-FL-treated mice. Furthermore, the proliferation of spinal microglia $14 \mathrm{~d}$ after peripheral nerve injury was also significantly reduced in CatS ${ }^{-/-}$, Z-FL-treated, or splenectomized mice. Moreover, a previous publication indicates that the presence of $\mathrm{CD}^{+}{ }^{+}$T-cells is robust in the dorsal root ganglion (DRG) of feline immunodeficiency virus-infected animals (Zhu et al., 2006). In our preliminary experiments, a moderate infiltration of $\mathrm{CD}^{+}{ }^{+} \mathrm{T}$-cells in the ipsilateral side of DRG was observed $7 \mathrm{~d}$ after peripheral nerve injury. Therefore, it is concluded that the $\mathrm{CD} 4{ }^{+}$T-cell-derived INF- $\gamma$ appears to be responsible for the reactivation of microglia, which is necessary for the maintenance of neuropathic pain.

Clark et al. (2007) demonstrated that daily intrathecal administration of morpholinurea-leucine-homophenylalanin-vinyl phenyl sulfate ( $30 \mathrm{nmol}$ ), an irreversible inhibitor of CatS, from 7 to $14 \mathrm{~d}$ following peripheral nerve injury significantly reduced established neuropathic allodynia. They have demonstrated that microglial CatS contributes to the maintenance of neuropathic pain. In the dorsal spinal cord, microglial CatS liberates neuronal fractalkine to stimulate 338 MAPK phospholylation in microglia. We observed that the mean level of p38 MAPK phospholylation and mature IL- $1 \beta$ was significantly reduced in the spinal cord of $\mathrm{CatS}^{-1-}$ mice even $3 \mathrm{~d}$ after peripheral nerve injury, suggesting that microglial CatS contributes to the induction, rather than the maintenance, of neuropathic pain. In the present study, Z-FL significantly attenuated the maintenance phase, but not the induction phase, of neuropathic pain, whereas CatS deficiency significantly attenuated both phases. This may be explained by the different peripheral and central roles of CatS. Z-FL, which cannot cross the blood-spinal cord barrier, only inhibits the CatS activity of dendritic cells, whereas CatS deficiency depletes the CatS activities of both dendritic cells and microglia. In any case, the exact reasons for the discrepant findings regarding microglial CatS remain to be elucidated in future studies.

In conclusion, although agents that have immunosuppressive and/or immunomodulatory properties significantly could provide significant benefits in animal models of neuropathic pain, the clinical application of these agents is considered to be difficult because of their severe side effects. Our present observations strongly suggest that peripherally active selective CatS inhibitors could be a safer therapeutic option for the pharmacological treatment of neuropathic pain, because they can avoid the induction of off-target side effects.

\section{References}

Austin PJ, Kim CF, Perera CJ, Moalem-Taylor G (2012) Regulatory T cells attenuate neuropathic pain following peripheral nerve injury and experimental autoimmune neuritis. Pain 153:1916-1931. CrossRef Medline

Cao L, DeLeo JA (2008) CNS-infiltrating CD4 ${ }^{+}$T lymphocytes contribute to murine spinal nerve transection-induced neuropathic pain. Eur J Immunol 38:448-458. CrossRef Medline

Chaplan SR, Bach FW, Pogrel JW, Chung JM, Yaksh TL (1994) Quantitative assessment of tactile allodynia in the rat paw. J Neurosci Methods 53:5563. CrossRef Medline

Clark AK, Yip PK, Grist J, Gentry C, Staniland AA, Marchand F, Dehvari M, Wotherspoon G, Winter J, Ullah J, Bevan S, Malcangio M (2007) Inhibition of spinal microglial cathepsin $S$ for the reversal of neuropathic pain. Proc Natl Acad Sci U S A 104:10655-10660. CrossRef Medline

Coste O, Pierre S, Marian C, Brenneis C, Angioni C, Schmidt H, Popp L, 
Geisslinger G, Scholich K (2008) Antinociceptive activity of the S1Preceptor agonist FTY720. J Cell Mol Med 12:995-1004. CrossRef Medline

Costigan M, Moss A, Latremoliere A, Johnston C, Verma-Gandhu M, Herbert TA, Barrett L, Brenner GJ, Vardeh D, Woolf CJ, Fitzgerald M (2009) $\mathrm{T}$-cell infiltration and signaling in the adult dorsal spinal cord is a major contributor to neuropathic pain-like hypersensitivity. J Neurosci 29: 14415-14422. CrossRef Medline

Driessen C, Bryant RA, Lennon-Duménil AM, Villadangos JA, Bryant PW, Shi GP, Chapman HA, Ploegh HL (1999) Cathepsin S controls the trafficking and maturation of MHC class II molecules in dendritic cells. J Cell Biol 147:775-790. CrossRef Medline

Hanisch UK, Kettenmann H (2007) Microglia: active sensor and versatile effector cells in the normal and pathologic brain. Nat Neurosci 10:13871394. CrossRef Medline

Hao HP, Doh-Ura K, Nakanishi H (2007) Impairment of microglial responses to facial nerve axotomy in cathepsin S-deficient mice. J Neurosci Res 85:2196-2206. CrossRef Medline

Hayashi Y, Yoshida M, Yamato M, Ide T, Wu Z, Ochi-Shindou M, Kanki T, Kang D, Sunagawa K, Tsutsui H, Nakanishi H (2008) Recerse of agedependent memory impairment and mitochondrial DNA damage in microglia by an overexpression of human mitochondrial transcription factor A in mice. J Neurosci 28:8624-8634. CrossRef Medline

Hayashi Y, Kawaji K, Sun L, Zhang X, Koyano K, Yokoyama T, Kohsaka S, Inoue K, Nakanishi H (2011) Microglial $\mathrm{Ca}^{2+}$-activated $\mathrm{K}^{+}$channels are possible molecular targets for the analgesic effects of S-ketamine on neuropathic pain. J Neurosci 31:17370-17382. CrossRef Medline

Kawanokuchi J, Mizuno T, Takeuchi H, Kato H, Wang J, Mitsuma N, Suzumura A (2006) Production of interferon- $\gamma$ by microglia. Mult Scler 12: 558-564. CrossRef Medline

Leger T, Grist J, D’Acquisto, Clark AK, Malcangio M (2011) Glatiramer acetate attenuates neuropathicallodynia through modulation of adaptive immune cells. J Neuroimmunol 234:19-26. CrossRef Medline

Liu H, Shiryaev SA, Chernov AV, Kim Y, Shubayev I, Remacle AG, Baranovskaya S, Golubkov VS, Strongin AY, Shubayev VI (2012) Immunodomain fragments of myelin basic protein initiate $\mathrm{T}$ cell-dependent pain. J Neuroinflammation 9:119. CrossRef Medline

McDevitt HO, Chinitz A (1969) Genetic control of the antibody response: relationship between immune response and histocompatibility (H-2) type. Science 163:1207-1208. CrossRef Medline

Moalem G, Xu K, Yu L (2004) T lymphocytes play a role in neuropathic pain following peripheral nerve injury in rats. Neuroscience 129:767-777. CrossRef Medline

Nakagawa TY, Brissette WH, Lira PD, Griffiths RJ, Petrushova N, Stock J, McNeish JD, Eastman SE, Howard ED, Clarke SR, Rosloniec EF, Elliott EA, Rudensky AY (1999) Impaired invariant chain degradation and antigen presentation and diminished collagen-induced arthritis in cathepsin S null mice. Immunity 10:207-217. CrossRef Medline

Nakanishi H (2003) Microglial functions and proteases. Mol Neurobiol 27: 163-176. CrossRef Medline

Padi SS, Shi XQ, Zhao YQ, Ruff MR, Baichoo N, Pert CB, Zhang J (2012) Attenuation of rodent neuropathic pain by an orally active peptide, RAP103, which potently blocks CCR2- and CCR5-mediated monocyte chemotaxis and inflammation. Pain 153:95-106. CrossRef Medline
Petanceska S, Canoll P, Devi LA (1996) Expression of rat cathepsin S in phagocytic cells. J Biol Chem 271:4403-4409. CrossRef Medline

Pierre P, Mellman I (1998) Developmental regulation of invariant chain proteolysis control MHC class II trafficking in mouse dendritic cells. Cell 93:1135-1145. CrossRef Medline

Riese RJ, Shi GP, Villadangos J, Stetson D, Driessen C, Lennon-Dumenil AM, Chu CL, Naumov Y, Behar SM, Ploegh H, Locksley R, Chapman HA (2001) Regulation of CD1 function and NK1.1 ${ }^{+} \mathrm{T}$ cell selection and maturation by cathepsin S. Immunity 15:909-919. CrossRef Medline

Scholz J, Woolf CJ (2007) The neuropathic pain triad: neurons, immune cells and glia. Nat Neurosci 10:1361-1368. CrossRef Medline

Shi GP, Villadangos JA, Dranoff G, Small C, Gu L, Haley KJ, Riese R, Ploegh HL, Chapman HA (1999) Cathepsin S required for normal MHC class II peptide loading and germinal center development. Immunity 10:197206. CrossRef Medline

Sun L, Wu Z, Hayashi Y, Peters C, Tsuda M, Inoue K, Nakanishi H (2012) Microglial cathepsin B contributes to the initiation of peripheral inflammation-induced chronic pain. J Neurosci 32:11330-11342. CrossRef Medline

Tsuda M, Shigemoto-Mogami Y, Koizumi S, Mizokoshi A, Kohsaka S, Salter MW, Inoue K (2003) $\mathrm{P}_{2} \mathrm{X}_{4}$ receptors induced in spinal microglia gate tactile allodynia after nerve injury. Nature 424:778-783. CrossRef Medline

Tsuda M, Masuda T, Kitano J, Shimoyama H, Tozaki-Saitoh H, Inoue K (2009) IFN- $\gamma$ receptor signaling mediates spinal microglia activation driving neuropathic pain. Proc Natl Acad Sci U S A 106:8032-8037. CrossRef Medline

van Zwam M, Huizinga R, Heijmans N, van Meurs M, Wierenga-Wolf AF, Melief MJ, Hintzen RQ, 't Hart BA, Amor S, Boven LA, Laman JD (2009) Surgical excision of CNS-draining lymph nodes reduces relapse severity in chronic-relapsing experimental autoimmune encephalomyelitis. J Pathol 217:543-551. CrossRef Medline

Villadangos JA, Riese RJ, Peters C, Chapman HA, Ploegh HL (1997) Degradation of mouse invariant chain: roles of cathepsin $\mathrm{S}$ and $\mathrm{D}$ and the influence of major histocompatibility complex polymorphism. J Exp Med 186:549-560. CrossRef Medline

Walker B, Lynas JF, Meighan MA, Brömme D (2000) Evaluation of dipeptide $\alpha$-keto- $\beta$-aldehydes as new inhibitors of cathepsin S. Biochem Biophys Res Commun 275:401-405. CrossRef Medline

Watkins LR, Milligan ED, Maier SF (2001) Glial activation: a driving force for pathological pain. Trends Neurosci 24:450-455. CrossRef Medline

Wu Z, Sun L, Hashioka S, Yu S, Schwab C, Okada R, Hayashi Y, McGeer PL, Nakanishi H (2013) Differential pathways for interleukin- $1 \beta$ production activated by chromogranin $A$ and amyloid $\beta$ in microglia. Neurobiol Aging 34:2715-2725. CrossRef Medline

Zhang J, Shi XQ, Echeverry S, Mogil JS, De Koninck Y, Rivest S (2007) Expression of CCR2 in both resident and bone marrow-derived microglia plays a critical role in neuropathic pain. J Neurosci 27:12396-12406. CrossRef Medline

Zhu Y, Antony J, Liu S, Martinez JA, Giuliani F, Zochodne D, Power C (2006) CD8 + lymphocyte-mediated injury of dorsal root ganglion neurons during lentivirus infection: CD154-dependent cell contact neurotoxicity. J Neurosci 26:3396-3403. CrossRef Medline 